Bull. Chem. Soc. Ethiop. 2021, 35(2), 243-255.

ISSN 1011-3924

(c) 2021 Chemical Society of Ethiopia and The Authors

Printed in Ethiopia

DOI: https://dx.doi.org/10.4314/bcse.v35i2.3

Online ISSN 1726-801X

\title{
LEVELS OF MAJOR AND TRACE METALS IN EGGPLANT AND SOIL
}

\author{
Kenbigegn Asafew and Bhagwan Singh Chandravanshi* \\ Department of Chemistry, College of Natural and Computational Sciences, Addis Ababa \\ University, P.O. Box 1176, Addis Ababa, Ethiopia
}

(Received May 9, 2021; Revised October 13, 2021; Accepted October 18, 2021)

\begin{abstract}
Eggplant is one of the widely used edible vegetables in the world including Ethiopia. The aim of this study was to determine the metal contents of eggplants and their corresponding soils collected from five different areas of Ethiopia. Levels of nine selected metals ( $\mathrm{Na}, \mathrm{Ca}, \mathrm{Mn}, \mathrm{Fe}, \mathrm{Cu}, \mathrm{Ni}, \mathrm{Zn}, \mathrm{Pb}$ and $\mathrm{Cd}$ ) were determined using flame atomic absorption spectrometry. The mean concentration ranges $(\mathrm{mg} / \mathrm{kg})$ of the metals in eggplant were $\mathrm{Na}(1,384-1,917)>\mathrm{Ca}(110-158)>\mathrm{Fe}(55.9-94.8)>\mathrm{Mn}(34.5-44.2)>\mathrm{Zn}(17.9-29.2)>\mathrm{Cu}(4.3-$ $10.0)>\mathrm{Pb}(1.8-4.5)$ and in soil Fe $(4,714-5,508)>\mathrm{Na}(843-1,120)>\mathrm{Ca}(237-788), \mathrm{Mn}(617-763)>\mathrm{Zn}(50.7-$ 99.4) $>\mathrm{Cu}(44.8-74.0)>\mathrm{Pb}(13.8-15.8)$, respectively. $\mathrm{Ni}$ and $\mathrm{Cd}$ were below the detection limit. The results indicated that eggplant is a good source of essential macro and micro metals. It is also free from toxic metal $\mathrm{Cd}$. However, it contains higher level of Pb, well above the WHO/FAO permissible level. The bioavailability of the metals in eggplant was investigated by analysis of soil $\mathrm{pH}$, electrical conductivity, total dissolved solid and salinity. Transfer factor exhibited a higher accumulation of $\mathrm{Na}$ from the soil to the eggplant but for the other metals it was $<1$.
\end{abstract}

KEY WORDS: Eggplant, Minerals, Soil properties, Transfer factor, Ethiopia

\section{INTRODUCTION}

Vegetable is any edible part of a plant, fungus or several algae, which is not sugary to taste [1]. Vegetables belonging to the Solanaceae family have great importance, because they have around 90 genera and 3000-4000 species. Plants such as potato, tomato, eggplant, bell pepper and pepper from Solanaceae family are widely used by humans mainly for food.

The fruit of the eggplant (Solanum melangema) is botanically classified as a berry and contains many edible soft seeds that are bitter because they contain nicotinoid alkaloids. The name of eggplant differs from country to country. It is known as brinjal in England, baigan in India, deberjan in Ethiopia and many more names all over the world. The varieties of eggplant lead to different shapes, sizes and colors of its fruit. The skin of the eggplant has many colors but the purple, green and white are more common [2]. The shape of fruit varies from oblong, ovoid, to long cylindrical. Bitterness in eggplant is due to the presence of glycol alkaloids [3].

Eggplant is generally cultivated as fruit vegetable in sub-tropical and tropical regions of the world. Eggplant is a high-yielding crop and is well-adapted to hot and wet environments. The highest production of eggplant is coming from China and India. Egypt, Turkey and Indonesia have equal rate in the production of eggplant [4].

Vegetables are appreciated because they contribute with many nutrients to the human diet, such as macro minerals $\mathrm{Na}, \mathrm{K}, \mathrm{Ca}, \mathrm{Mg}, \mathrm{P}$, and also contain trace minerals such as $\mathrm{Cu}, \mathrm{Cr}, \mathrm{Fe}$, $\mathrm{Mn}, \mathrm{Zn}$, Co and Ni [5]. Eggplant is a good source of minerals and vitamins and in total nutritional value. Eggplant is a popular vegetable that is consumed globally on a daily basis, which is rich in dietary fiber, low in calories and protein, phenolic constituents, water soluble sugars, free reducing sugars and folate [6]. Eggplant contains vitamins such as B6, $\mathrm{K}$ and $\mathrm{C}$. Eggplant is a good source of essential minerals such as $\mathrm{K}, \mathrm{Mg}, \mathrm{Na}, \mathrm{P}, \mathrm{Cu}, \mathrm{Cr}, \mathrm{Fe}, \mathrm{Mn}, \mathrm{Ni}$ and $\mathrm{Zn}$ [7]. Eggplant is an important source of nutrients in the diets of low income consumers [8].

${ }^{*}$ Corresponding author. E-mail: bscv2006@yahoo.com

This work is licensed under the Creative Commons Attribution 4.0 International License 
Eggplant contains many bioactive constituents that have healthy effects, for example flavonoids, minerals, vitamins, and other products which possess several medicinal properties [9]. The phenolic compounds reduce risk of developing chronic diseases such as cardiovascular disease, cancer, diabetes and delayed vital functions disorders with age [10]. The American Diabetes Association recommends an eggplant-based diet as a choice for the controlling of type-2 diabetes because of the high-insoluble fiber and low soluble carbohydrate contents. Especially white eggplant is used to treat type-2 diabetes [11].

Eggplant has also been used in traditional medicine to treat many diseases. Eggplant is also used as a purgative, to ease urination, and to increase sex drive or sex initiative [12]. Eggplant is used for the treatment of several diseases, including diabetes, arthritis, asthma, cancer and bronchitis. Eggplant is ranked among the top ten vegetables for the free radical scavenging activity [9].

Evaluation of micronutrients levels of vegetables is a growing trend in nutritional studies throughout the world as different micronutrients are necessary for different body functions [13]. Heavy metals are the major contaminants of food, because significant level of toxic chemical elements are frequently released into the seas, rivers, lakes and irrigation channels from industrial wastes and other anthropogenic sources [14]. Plants accumulate heavy metals (toxicants) like $\mathrm{Cd}$ and $\mathrm{Pb}$ from contaminated soil and water. Human and animals get affected or contaminated by accumulating these metals through the consumption of contaminated plants or vegetables cultivated in contaminated soils and water [15]. The heavy metals are widely distributed in environment, in soil, plants and animal tissues. The heavy metals have high impact on the contamination of soil and water and may affect vegetables, plants and human health because they are persistent [16].

Environmental factors like temperature, soil, water and genetic factors have their own effects in the chemical composition as well as the physical characteristics of eggplant. Therefore, it is important to determine the metal content of eggplant. Soil is essential for growth of vegetables so it is important to determine the metal contents as well as the $\mathrm{pH}$, salinity, total dissolved solid and electrical conductivity of the soil. Soil serves as a natural medium for growth of plants [17]. Soil organic carbon, nitrogen, phosphorus, and potassium are the major indicators of soil quality and fertility as they are strongly connected to plant growth and productivity [18].

Heavy metals occupy a special position in soil chemistry because they play very important physiological roles in nature. The solubility of heavy metal ions in soil is mainly influence by many factors such as $\mathrm{pH}$, conductivity, and moisture content. Heavy metals may enter the food chain as a result of their uptake by edible plants [17]. Measuring the $\mathrm{pH}$ and electrical conductivity (EC) parameters provides valuable information for assessing soil condition for growth of plant, nutrient cycling and biological activity [19].

Some studies have been done on the levels of metals in the eggplant in some countries, South America [2], Turkey [20, 21] and Bangladesh [22, 23]. Recently, some studies have been done on the levels of metals in selected vegetables in Addis Ababa, Ethiopia [24], onion around Meki Town and Lake Ziway, Ethiopia [25], Swiss chard, Addis Ababa, Ethiopia [26] and lettuce from five farms in Ethiopia [27]. However, there is no any report in the literature on the levels of metals in eggplant cultivated in Ethiopia.

The main objective of this study was to determine the metal contents in eggplants and their corresponding soil collected from five different areas of Ethiopia by flame atomic absorption spectrometry (FAAS). Specifically, the scope of the study was (i) to determine metal contents of eggplants and corresponding soil by FAAS, (ii) to determine EC, pH, salinity and total dissolved solid (TDS) content of soil to assess the bioavailability of metals in the eggplant, (iii) to study the correlation of the metals in the eggplants and their corresponding soil, and (iv) to compare the results of this study with results reported in literature. 


\section{EXPERIMENTAL}

\section{Equipment and apparatus}

Plastic knife was used to separate the skin of the eggplant from the fruit. Electronic balance (OPTECH, A205EC, Italy) with precision of $\pm 0.0001 \mathrm{~g}$ was used for weighing both eggplant and soil sample. Ceramic mortar and pestle were used to grind eggplant and soil samples. 250 $\mathrm{mL}$ round bottom flasks fitted with reflux condenser were used with Kjeldahl digestion block (UK) to digest the dried and powdered eggplant and soil sample. A refrigerator (Hitachi, Tokyo, Japan) was used to keep the digested sample until the analysis. Volumetric flasks $(50 \mathrm{~mL})$ were used during dilution and preservation of samples and preparation of metals standard solutions. Micro pipettes $(0-100 \mu \mathrm{L}$ and $100-1000 \mu \mathrm{L})$ were used for measuring volumes. $\mathrm{pH} /$ ion meter (WTW Inolab $\mathrm{pH} / \mathrm{ION}$ Level 2, Germany) using unfilled $\mathrm{pH}$ glass electrode was used to measure the $\mathrm{pH}$ of soil sample. The EC, salinity and TDS of soil samples were measured using Thermo Orion EC meter (Orion 162A) (USA). Magnetic stirrer was used to stir the mixture of soil sample with distilled water. ZEEnit 700p (Germany) flame atomic absorption spectrometry (FAAS) was used for the determination of various metals viz. $\mathrm{Na}, \mathrm{Ca}, \mathrm{Mn}, \mathrm{Fe}, \mathrm{Cu}, \mathrm{Zn}, \mathrm{Ni}, \mathrm{Pb}$ and Cd.

\section{Chemicals and reagents}

All chemicals and reagents used in the study were of analytical grade. $\mathrm{HNO}_{3}(69.5 \%$ reagent grade, ACS, ISO, European Union), $\mathrm{HClO}_{4}(70 \%$, Research-lab Fine Chem Indusrties, India) and $\mathrm{HCl}(37 \%$, Riedel-de Haen, AG, Germany) were used for digestion of eggplant and soil samples. Stock standard solution containing $1000 \mathrm{mg} / \mathrm{L}$, in $2 \% \mathrm{HNO}_{3}$, of the metal $\mathrm{Na}, \mathrm{Ca}, \mathrm{Mn}$, $\mathrm{Fe}, \mathrm{Cu}, \mathrm{Zn}, \mathrm{Ni}, \mathrm{Pb}$, and $\mathrm{Cd}$ (Buck Scientific Puro-Graphic ${ }^{\mathrm{tm}}$, USA) were used for the preparation of calibration standard and spiking experiments.

\section{Description of sampling sites}

The sampling sites at Bishoftu, Koka, Meki, Ziway and Alemtena, where eggplant and soil samples were collected are located in Oromia region of Ethiopia (Figure 1). These sampling sites were selected due to their maximum production of eggplant in Ethiopia. The Oromia area is under continuous cultivation throughout the year and has been supplying wide variety of vegetables like eggplant, tomato, onion, cabbage, green pepper, potato, etc. to the capital city and for local consumption for a long period of time. Modern farming practices such as mechanized farming, application of agro-chemicals and selected seeds are significant agricultural inputs for getting better yield in the area.

\section{Collection and preparation of eggplant and soil samples}

About one-kilogram eggplants were collected from each of the five different sample sites in polyethylene bags. The eggplant samples kept in polyethylene bags were transported to the laboratory of the Chemistry Department of Addis Ababa University. The skin of the eggplant was separated from the fruit and the fruit was chopped into small pieces using plastic knife in order to facilitate drying. The samples were air-dried for one week. The dried samples were ground into powder using mortar and pestle and sieved to $0.425 \mathrm{~mm}$ mesh size. The sieved samples were stored in polyethylene bags and placed in a clean and dry place until digestion. 


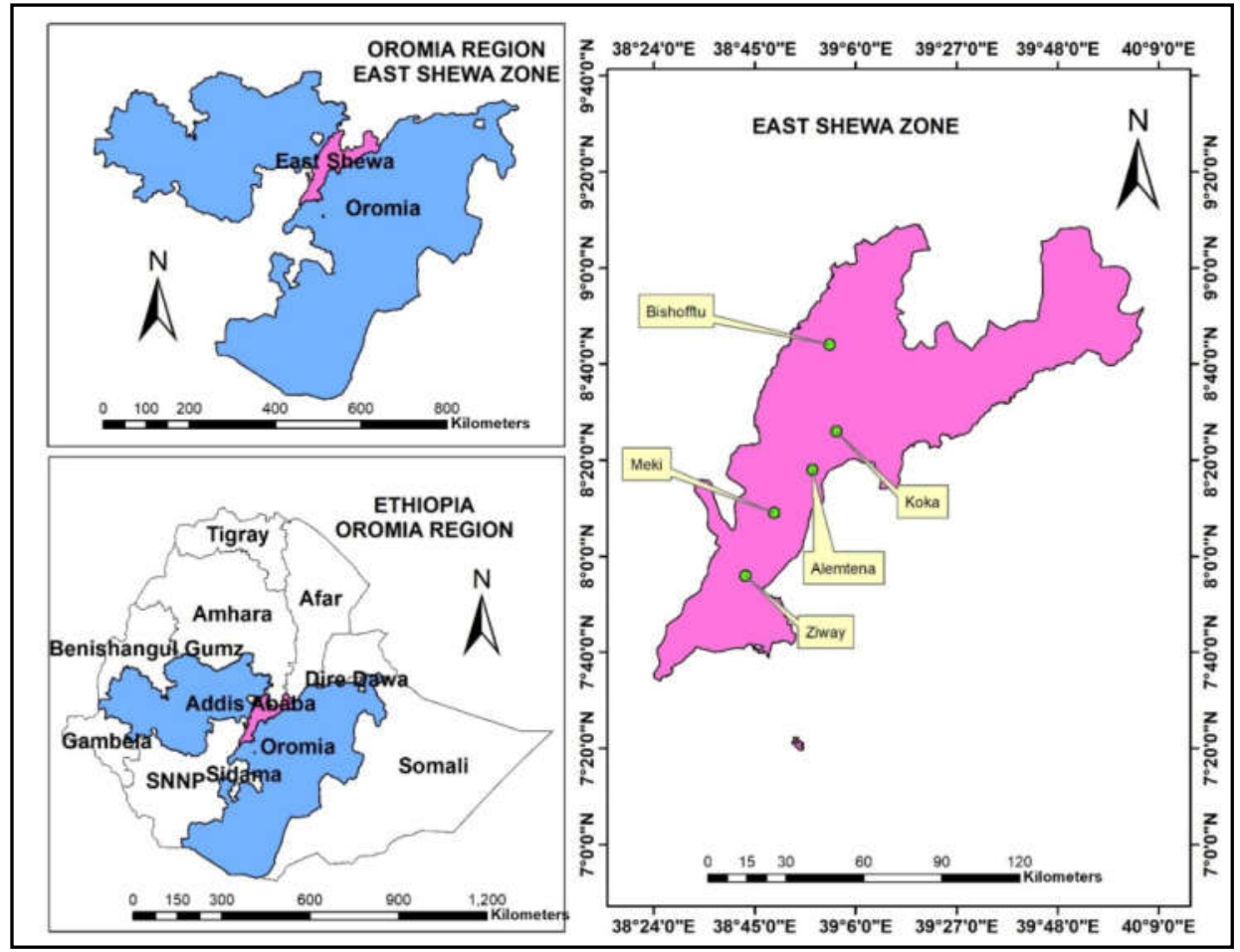

Figure 1. Map of Ethiopia showing sites from where samples were collected.

The soil samples were collected from five sample sites from the base of the uprooted eggplant using auger and placed in polyethylene bags. The soil samples were dried at ambient temperature for 10 days and crushed into powder using mortar and pestle and sieved to 0.425 $\mathrm{mm}$ mesh size. The sieved samples were stored in polyethylene bags and placed in a clean and dry place until the time of digestion.

\section{Sample decomposition}

A wet digestion method was used for sample decomposition in this study. Wet acid digestion is based on changing different digestion parameters like volume ratio of reagents added, digestion temperature and digestion time. The optimization of digestion procedures described in next sections was carried out based on the usage of smaller reagent volume, shorter digestion time and reasonable mild temperature for obtaining clear and colorless solutions of the resulting digestates.

\section{Optimization of digestion procedure for eggplants}

$0.5 \mathrm{~g}$ of powder and homogenized sample was transferred to a $250 \mathrm{~mL}$ round bottom flask. Different volumes of $\mathrm{HNO}_{3}$ and $\mathrm{HClO}_{4}$ at different proportions $(\mathrm{v} / \mathrm{v})$ were added and digested at different temperatures $\left(150,180,210,240,270\right.$ and $\left.300{ }^{\circ} \mathrm{C}\right)$ for different periods of time $(105$, 
$120,135,165$ and $180 \mathrm{~min}$ ). The optimization procedure was determined based on the formation of a clear colorless solution. The digested solution was allowed to cool down and $5 \mathrm{~mL}$ of distilled water was added to dissolve residue formed on cooling and gradually swirled and filtered into $50 \mathrm{~mL}$ volumetric flask through Whatman 93 filter paper. The clear solution was diluted up to $50 \mathrm{~mL}$ in a volumetric flask with distilled water and kept in a refrigerator until analysis using FAAS. The optimization procedures for the sample preparation are shown in Table 1.

Table 1. Different conditions tested for optimization of digestion procedure for $0.5 \mathrm{~g}$ of eggplant samples.

\begin{tabular}{|c|c|c|c|c|c|c|}
\hline 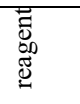 & Trial & Reagents used & $\begin{array}{l}\text { Reagent } \\
\text { volume ratio } \\
(\mathrm{mL})\end{array}$ & $\begin{array}{l}\text { Temperature } \\
\left({ }^{\circ} \mathrm{C}\right)\end{array}$ & $\begin{array}{l}\text { Digestion } \\
\text { time (h) }\end{array}$ & Observation \\
\hline \multirow{6}{*}{ 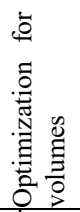 } & 1 & $\mathrm{HNO}_{3}: \mathrm{HClO}_{4}$ & $3: 1$ & 300 & $3: 00$ & Cloudy colorless \\
\hline & 2 & $\mathrm{HNO}_{3}: \mathrm{HClO}_{4}$ & $2: 2$ & 300 & $3: 00$ & Clear light yellow \\
\hline & 3 & $\mathrm{HNO}_{3}: \mathrm{HClO}_{4}$ & $4: 1$ & 300 & $3: 00$ & Clear and colorless* \\
\hline & 4 & $\mathrm{HNO}_{3}: \mathrm{HClO}_{4}$ & $3: 2$ & 300 & $3: 00$ & Clear light yellow \\
\hline & 5 & $\mathrm{HNO}_{3}: \mathrm{HClO}_{4}$ & $5: 1$ & 300 & $3: 00$ & Clear and colorless \\
\hline & 6 & $\mathrm{HNO}_{3}: \mathrm{HClO}_{4}$ & $4: 2$ & 300 & $3: 00$ & Deep yellow \\
\hline \multirow{6}{*}{ 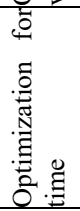 } & 1 & $\mathrm{HNO}_{3}: \mathrm{HClO}_{4}$ & $4: 1$ & 300 & $1: 45$ & Clear and light yellow \\
\hline & 2 & $\mathrm{HNO}_{3}: \mathrm{HClO}_{4}$ & $4: 1$ & 300 & $2: 00$ & Clear and light yellow \\
\hline & 3 & $\mathrm{HNO}_{3}: \mathrm{HClO}_{4}$ & $4: 1$ & 300 & $2: 15$ & Clear and light yellow \\
\hline & 4 & $\mathrm{HNO}_{3}: \mathrm{HClO}_{4}$ & $4: 1$ & 300 & $2: 30$ & Clear and colorless* \\
\hline & 5 & $\mathrm{HNO}_{3}: \mathrm{HClO}_{4}$ & $4: 1$ & 300 & $2: 45$ & Clear and colorless \\
\hline & 6 & $\mathrm{HNO}_{3}: \mathrm{HClO}_{4}$ & $4: 1$ & 300 & $3: 00$ & Clear and colorless \\
\hline \multirow{6}{*}{ 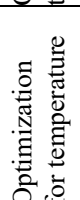 } & 1 & $\mathrm{HNO}_{3}: \mathrm{HClO}_{4}$ & $4: 1$ & 150 & $2: 30$ & Yellow solution \\
\hline & 2 & $\mathrm{HNO}_{3}: \mathrm{HClO}_{4}$ & $4: 1$ & 180 & $2: 30$ & Yellow solution \\
\hline & 3 & $\mathrm{HNO}_{3}: \mathrm{HClO}_{4}$ & $4: 1$ & 210 & $2: 30$ & Clear and light yellow \\
\hline & 4 & $\mathrm{HNO}_{3}: \mathrm{HClO}_{4}$ & $4: 1$ & 240 & $2: 30$ & Cloudy and colorless \\
\hline & 5 & $\mathrm{HNO}_{3}: \mathrm{HClO}_{4}$ & $4: 1$ & 270 & $2: 30$ & Clear and colorless* \\
\hline & 6 & $\mathrm{HNO}_{3}: \mathrm{HClO}_{4}$ & $4: 1$ & 300 & $2: 30$ & Clear and colorless \\
\hline
\end{tabular}

*Shows the optimized volume ratio, time and temperature.

Optimization of digestion procedure for soil sample

$0.5 \mathrm{~g}$ of powder and homogenized soil sample was transferred to a $250 \mathrm{~mL}$ round bottom flask. Different volumes of $\mathrm{HNO}_{3}, \mathrm{HClO}_{4}$ and $\mathrm{HCl}$ at quantified proportions (v/v) were added and digested at different temperatures $\left(150,180,210,240,270\right.$ and $\left.300{ }^{\circ} \mathrm{C}\right)$ for different period of time $(105,120,135,165$ and $180 \mathrm{~min})$. The optimization procedure was determined based on the formation of a clear colorless solution. The digested solution was allowed to cool and $5 \mathrm{~mL}$ of distilled water was added to dissolve residue formed on cooling and gradually swirled and filtered into $50 \mathrm{~mL}$ volumetric flask through Whatman 93 filter paper. The clear solution was diluted up to $50 \mathrm{~mL}$ in a volumetric flask with distilled water and kept in a refrigerator until analysis using FAAS. The optimization procedures for the soil sample preparation are shown in Table 2.

\section{Digestion of eggplant samples}

Using the optimized conditions (Table 1), $0.5 \mathrm{~g}$ eggplant powdered sample was transferred to a $250 \mathrm{~mL}$ round bottom flask and $4 \mathrm{~mL} 69.5 \% \mathrm{HNO}_{3}$ and $1 \mathrm{~mL} 70 \% \mathrm{HClO}_{4}$ were added. The mixture was digested on a Kjeldhal digestion block for the optimized time of 2:30 h at the optimized temperature $270{ }^{\circ} \mathrm{C}$. After $2: 30 \mathrm{~h}$ of the digestion time, the digested solution was allowed to cool to room temperature for about $30 \mathrm{~min}$ without disassembling the condenser. 
After disassembling the condenser, $10 \mathrm{~mL}$ of distilled water was added to the solution. This was done by rinsing the neck of the round bottom flask and tip of condenser that was in contact to dissolve the residue formed due to cooling and minimizing dilution of filter paper by digest residue while filtering with Whatman $110 \mathrm{~mm}$ filter paper into $50 \mathrm{~mL}$ volumetric flask. Finally, the cooled solution was filled up to the mark with distilled water. This procedure was done three times for each eggplant samples. The digestion of the blank reagent was done simultaneously with the samples. All the solutions were kept in refrigerator until the analysis.

Table 2. Different conditions tested for optimization of digestion procedure for $0.5 \mathrm{~g}$ of soil samples.

\begin{tabular}{|c|c|c|c|c|c|c|}
\hline 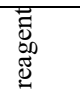 & Trial & Reagents used & $\begin{array}{l}\text { Reagent } \\
\text { volume } \\
\text { ratio }(\mathrm{mL})\end{array}$ & $\begin{array}{l}\text { Temperat } \\
\text { ure }\left({ }^{\circ} \mathrm{C}\right)\end{array}$ & $\begin{array}{l}\text { Digestion } \\
\text { time (h) }\end{array}$ & Observation \\
\hline tᄒ & 1 & $\mathrm{HNO}_{3}: \mathrm{HCl}: \mathrm{HClO}_{4}$ & $1: 1: 1$ & 300 & $3: 00$ & Deep yellow \\
\hline \multirow{5}{*}{ 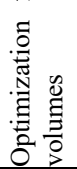 } & 2 & $\mathrm{HNO}_{3}: \mathrm{HCl}: \mathrm{HClO}_{4}$ & $2: 1: 1$ & 300 & $3: 00$ & Deep yellow \\
\hline & 3 & $\mathrm{HNO}_{3}: \mathrm{HCl}: \mathrm{HClO}_{4}$ & $3: 2: 1$ & 300 & $3: 00$ & Light yellow \\
\hline & 4 & $\mathrm{HNO}_{3}: \mathrm{HCl}: \mathrm{HClO}_{4}$ & $3: 1: 1$ & 300 & $3: 00$ & Clear and colorless* \\
\hline & 5 & $\mathrm{HNO}_{3}: \mathrm{HCl}: \mathrm{HClO}_{4}$ & $6: 2: 2$ & 300 & 3:00 & Clear and colorless \\
\hline & 6 & $\mathrm{HNO}_{3}: \mathrm{HCl}: \mathrm{HClO}_{4}$ & $6: 1: 1$ & 300 & $3: 00$ & Clear light yellow \\
\hline \multirow{6}{*}{ 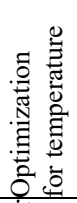 } & 1 & $\mathrm{HNO}_{3}: \mathrm{HCl}: \mathrm{HClO}_{4}$ & $3: 1: 1$ & 150 & 3:00 & Deep yellow \\
\hline & 2 & $\mathrm{HNO}_{3}: \mathrm{HCl}: \mathrm{HClO}_{4}$ & $3: 1: 1$ & 180 & 3:00 & Clear light yellow \\
\hline & 3 & $\mathrm{HNO}_{3}: \mathrm{HCl}: \mathrm{HClO}_{4}$ & $3: 1: 1$ & 210 & 3:00 & Clear light yellow \\
\hline & 4 & $\mathrm{HNO}_{3}: \mathrm{HCl}: \mathrm{HClO}_{4}$ & $3: 1: 1$ & 240 & 3:00 & Clear and light yellow \\
\hline & 5 & $\mathbf{H N O}_{3}: \mathbf{H C l}: \mathrm{HClO}_{4}$ & 3:1:1 & $270^{*}$ & 3:00 & Clear and colorless* \\
\hline & 6 & $\mathrm{HNO}_{3}: \mathrm{HCl}: \mathrm{HClO}_{4}$ & $3: 1: 1$ & 300 & 3:00 & Clear and colorless \\
\hline \multirow{6}{*}{ 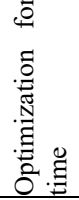 } & 1 & $\mathrm{HNO}_{3}: \mathrm{HCl}: \mathrm{HClO}_{4}$ & $3: 1: 1$ & 270 & $1: 45$ & Deep yellow \\
\hline & 2 & $\mathrm{HNO}_{3}: \mathrm{HCl}: \mathrm{HClO}_{4}$ & $3: 1: 1$ & 270 & $2: 00$ & Clear and light yellow \\
\hline & 3 & $\mathrm{HNO}_{3}: \mathrm{HCl}: \mathrm{HClO}_{4}$ & $3: 1: 1$ & 270 & $2: 15$ & Clear and light yellow \\
\hline & 4 & $\mathrm{HNO}_{3}: \mathrm{HCl}: \mathrm{HClO}_{4}$ & $3: 1: 1$ & 270 & $2: 30$ & Clear and light yellow \\
\hline & 5 & $\mathrm{HNO}_{3}: \mathrm{HCl}$ & 3:1:1 & 270 & $2: 45$ & Clear and colorless* \\
\hline & 6 & $\mathrm{HNO}_{3}: \mathrm{HCl}$ & $3: 1: 1$ & 270 & $3: 00$ & Clear and colorless \\
\hline
\end{tabular}

*Shows the optimized volume ratio volume ratio, time and temperature.

\section{Digestion of soil samples}

Using the optimized conditions (Table 2), $0.5 \mathrm{~g}$ soil powder samples were weighed and transferred to a $250 \mathrm{~mL}$ round bottom flask and $5 \mathrm{~mL}$ of $3: 1: 1$ ratio of $\mathrm{HNO}_{3}, \mathrm{HCl}$ and $\mathrm{HClO}_{4}$ were added. The mixture was digested on a Kjeldhal digestion block for the optimized time of $2: 30 \mathrm{~h}$ at the optimized temperature of $270{ }^{\circ} \mathrm{C}$. After $2: 30 \mathrm{~h}$ of the digestion time the digested solution was allowed to cool to room temperature for about $30 \mathrm{~min}$ without disassembling the condenser. After disassembling the condenser, $20 \mathrm{~mL}$ distilled water was added to the digest to dissolve the residue formed on cooling and vigorously swirled and filtered into $50 \mathrm{~mL}$ volumetric flask through Whatman $110 \mathrm{~mm}$ filter paper. Finally, the clear solution was diluted with distilled water. This procedure was done three times for each soil samples. The digestion of the blank reagent was done simultaneously with the samples. All the solutions were kept in refrigerator until the analysis.

Determination of $\mathrm{pH}$, conductivity, salinity and TDS of soil samples

Soil $\mathrm{pH}, \mathrm{EC}$, salinity and TDS of the soil samples were determined [19] by mixing $10 \mathrm{~g}$ of the soil with $25 \mathrm{~mL}$ of distilled water in $50 \mathrm{~mL}$ beaker. The mixture was stirred in a magnetic stirrer for $30 \mathrm{~min}$. The $\mathrm{pH}$ was measured after calibrating the $\mathrm{pH}$ meter with technical $\mathrm{pH}$ buffers of 4.01 (for acidic solutions) and 10.00 (for alkaline solutions). The other three parameters (EC, 
salinity and TDS) were determined after direct calibration with standard solution according to the procedure given in the instruction manual of the manufacturer [28].

Calibration of instrument for the determination of selected metals by FAAS

For the analysis of all eggplant and soil samples, FAAS instrument was calibrated with known concentration of standard solutions for each target metal. Calibration metal standard solutions were prepared for each of the metals from a standard solution containing $10 \mathrm{mg} / \mathrm{L}$ which was prepared from standard stock solutions that contained $1000 \mathrm{mg} / \mathrm{L}$. These standards were diluted with deionized water to obtain four working standards for each metal of interest. Three replicate runs were carried out for each sample. The concentration of $\mathrm{Na}, \mathrm{K}, \mathrm{Ca}, \mathrm{Mn}, \mathrm{Fe}, \mathrm{Ni}, \mathrm{Cu}, \mathrm{Zn}, \mathrm{Pb}$ and $\mathrm{Cd}$ were determined by FAAS in both the eggplant and soil samples. Calibration curves were prepared to determine the concentration of metals in the sample solutions. Calibration curve exhibited good linearity with $\mathrm{R}^{2}$ values ranged $>0.99$, which showed that the two variable concentration and absorbance had a good positive correlation and linearity.

\section{Validation of optimized procedure}

The efficiency of the optimized procedure was verified by adding the known concentration of each metal to $0.5 \mathrm{~g}$ sample of eggplant and soil. The spiked and non-spiked samples were digested and analyzed in the same way using optimized procedure of sample analysis. The results obtained from recovery analysis are shown in Table 3. The percentage of recovery was found to vary from 93 to $109 \%$ and 94 to $103 \%$ for eggplant and soil samples, respectively, which were within the acceptable range for all the metals.

Table 3. Recovery test results for the optimized procedure of eggplant and soil samples.

\begin{tabular}{|l|c|c|c|c|c|c|c|c|}
\hline \multirow{2}{*}{ Metals } & \multicolumn{4}{|c|}{ Eggplants } & \multicolumn{4}{|c|}{ Soil } \\
\cline { 2 - 9 } & $\mathrm{Na}$ & $\mathrm{Ca}$ & $\mathrm{Fe}$ & $\mathrm{Zn}$ & $\mathrm{Na}$ & $\mathrm{Ca}$ & $\mathrm{Fe}$ & $\mathrm{Zn}$ \\
\hline $\begin{array}{l}\text { Unspiked sample } \\
(\mathrm{mg} / \mathrm{kg})\end{array}$ & $1,451 \pm 1$ & $110 \pm 1$ & $94.8 \pm 0.6$ & $17.9 \pm 0.3$ & $1,016 \pm 1$ & $266 \pm 1$ & $5,508 \pm 1$ & $44.8 \pm 0.2$ \\
\hline$\%$ spiked & 20 & 50 & 50 & 50 & 20 & 50 & 20 & 50 \\
\hline Amount added (mg/kg) & 290 & 55 & 47 & 9 & 203 & 133 & 1102 & 22 \\
\hline Spiked sample (mg/kg) & $1721 \pm 1$ & $170 \pm 1$ & $140 \pm 1$ & $27 \pm 0.1$ & $1226 \pm 1$ & $391 \pm 1$ & $6,588 \pm 1$ & $70 \pm 0.1$ \\
\hline$\%$ Recovery & 93 & 109 & 96 & 101 & 103 & 94 & 98 & 100 \\
\hline
\end{tabular}

\section{RESULTS AND DISCUSSION}

\section{Levels of metals in eggplant samples}

The results of the analysis (Table 4) showed that metal contents of eggplant varied from the area to area where the eggplant was harvested. This variation could be attributed to the mineral composition of the soil in which the plant had been grown and also to the environmental factors influencing the mineral content of the plant. The concentration of metals in eggplant samples collected from Bishoftu was found as $\mathrm{Na}>\mathrm{Ca}>\mathrm{Fe}>\mathrm{Mn}>\mathrm{Zn}>\mathrm{Cu}>\mathrm{Pb}$. The pattern of concentration of the metal in eggplant collected from Meki, Alemtena and Ziway were the same as that of Bishoftu. But the distribution of the concentration of metals in eggplant samples collected from Koka was $\mathrm{Na}>\mathrm{Ca}>\mathrm{Fe}>\mathrm{Mn}>\mathrm{Zn}>\mathrm{Pb}>\mathrm{Cu}$.

The higher amounts of $\mathrm{Na}$ and $\mathrm{Pb}$ were found to occur in the sample collected from Koka as compared other sample sites. The concentration of $\mathrm{Ca}, \mathrm{Cu}$ and $\mathrm{Fe}$ were higher in Alemtena, Meki and Bishoftu sample sites, as compared to other sample sites. The concentrations of Mn 
and $\mathrm{Zn}$ were higher in the sample site of Ziway as compared to other sample sites. The concentrations $\mathrm{Na}$ were highest than other metals concentrations in each sample site and the concentrations of $\mathrm{Pb}$ were lowest than other metals in each sample site except Koka sample site. The concentrations of $\mathrm{Ni}$ and $\mathrm{Cd}$ in eggplant samples collected from five different sample sites were below the detection limit.

Table 4. Concentration of metals $(\mathrm{mg} / \mathrm{kg})$ in eggplant samples.

\begin{tabular}{|c|c|c|c|c|c|}
\hline \multirow{2}{*}{ Metals } & \multicolumn{5}{|c|}{ Concentration of metals (mean \pm SD, mg/kg, $\mathrm{n}=3$ ) } \\
\cline { 2 - 6 } & Bishoftu & Koka & Alemtena & Meki & Ziway \\
\hline $\mathrm{Na}$ & $1,451 \pm 1$ & $1,917 \pm 1$ & $1,858 \pm 1$ & $1,384 \pm 1$ & $1,600 \pm 1$ \\
\hline $\mathrm{Ca}$ & $110 \pm 1$ & $114 \pm 1$ & $158 \pm 1$ & $120 \pm 1$ & $135 \pm 1$ \\
\hline $\mathrm{Mn}$ & $39.5 \pm 0.1$ & $34.5 \pm 0.2$ & $41.8 \pm 0.4$ & $43.3 \pm 0.2$ & $44.2 \pm 0.3$ \\
\hline $\mathrm{Fe}$ & $94.8 \pm 0.6$ & $85.3 \pm 0.3$ & $55.9 \pm 0.3$ & $72.2 \pm 0.1$ & $85.0 \pm 0.2$ \\
\hline $\mathrm{Cu}$ & $6.40 \pm 0.02$ & $4.3 \pm 0.02$ & $6.5 \pm 0.01$ & $10.0 \pm 0.3$ & $6.7 \pm 0.01$ \\
\hline $\mathrm{Zn}$ & $17.9 \pm 0.1$ & $18.2 \pm 0.2$ & $26.3 \pm 0.5$ & $21.6 \pm 0.4$ & $29.2 \pm 0.2$ \\
\hline $\mathrm{Pb}$ & $4.20 \pm 0.01$ & $4.5 \pm 0.01$ & $1.8 \pm 0.01$ & $2.9 \pm 0.01$ & $3.6 \pm 0.03$ \\
\hline $\mathrm{Ni}$ & $\mathrm{BDL}$ & BDL & BDL & BDL & BDL \\
\hline $\mathrm{Cd}$ & BDL & BDL & BDL & BDL & BDL \\
\hline
\end{tabular}

BDL is below detection limit.

\section{Comparison of the heavy metal contents in eggplant sample with other reported values}

As shown in Table 5, the concentrations of $\mathrm{Mn}$ and $\mathrm{Pb}$ in eggplant of this study were higher than the concentration of $\mathrm{Mn}$ and $\mathrm{Pb}$ in other reported values. The concentration of $\mathrm{Cd}$ in eggplant is reported in some studies $[2,20,23]$ but it was not detected in the eggplants in this study. The concentration of $\mathrm{Cu}$ in the eggplant of this study is lower than those reported by researchers [20, $21,23]$ and but comparable with the study [2]. At the same time, it is much higher than that reported in the study of Rashid et al. [22]. The concentration of Fe in the eggplant of this study is comparable with the other studies [2,22] while it is lower than in the study of Uddin et al. [23]. The concentration of $\mathrm{Zn}$ in the eggplant is higher in the study of Demirezen and Aksoy [21] while the results of other studies are comparable with the results of present study. The concentration of Ni in the eggplant is reported in some studies [20,21], but it is not detected in present study. The concentrations of $\mathrm{Zn}$ and $\mathrm{Cu}$ in the eggplant of this study are well within the permissible levels of $\mathrm{WHO} / \mathrm{FAO}[29]$ in the fruits and vegetables. Ni and $\mathrm{Cd}$ are not detected in the present study. However, the concentration of $\mathrm{Pb}$ in the eggplant of this study is well above the permissible levels of $\mathrm{WHO} / \mathrm{FAO}[29]$ in the fruits and vegetables.

Table 5. Comparison of heavy metals concentration $(\mathrm{mg} / \mathrm{kg}$ ) of the eggplant with values (concentration) reported in the literature.

\begin{tabular}{|c|c|c|c|c|c|c|c|c|}
\hline $\mathrm{Zn}$ & $\mathrm{Cu}$ & $\mathrm{Mn}$ & $\mathrm{Fe}$ & $\mathrm{Ni}$ & $\mathrm{Cd}$ & $\mathrm{Pb}$ & Country origin & Reference \\
\hline 21.4 & 8.4 & 13.4 & 63.4 & $\mathrm{NR}$ & 2.40 & 3.24 & South America & {$[2]$} \\
\hline 35.8 & 0.13 & 28.8 & 96.8 & $\mathrm{NR}$ & $\mathrm{NR}$ & $\mathrm{NR}$ & Bangladesh & {$[22]$} \\
\hline 53.9 & 22.2 & $\mathrm{NR}$ & $\mathrm{NR}$ & 2.18 & 0.30 & 3.3 & Turkey & {$[21]$} \\
\hline 16.4 & 11.7 & $\mathrm{NR}$ & 285 & $\mathrm{NR}$ & $\mathrm{NR}$ & 0.24 & Bangladesh & {$[23]$} \\
\hline 39.7 & 14.4 & 8.2 & $\mathrm{NR}$ & 1.5 & 1.1 & $\mathrm{NR}$ & Turkey & {$[20]$} \\
\hline 50 & 40 & - & - & 1.0 & 0.2 & 0.3 & WHO/FAO & {$[29]$} \\
\hline 22.6 & 6.8 & 40.7 & 78.6 & $\mathrm{ND}$ & $\mathrm{ND}$ & 3.4 & Ethiopia & This study \\
\hline
\end{tabular}

$\mathrm{NR}=$ not reported. $\mathrm{ND}=$ not detected. $* \mathrm{WHO} / \mathrm{FAO}$ permissible levels in fruits and vegetables. 


\section{The concentration of metals in soil samples}

Table 6 shows that the metal contents of soil samples varied between the areas in which the plant was cultivated. This variation can be attributed to the mineral composition of soil in which the plant has been grown and the environmental factors influence the mineral content of the plant. The distribution of the concentration of metals in soil samples that were collected from Koka, Alemtena and Meki were $\mathrm{Fe}>\mathrm{Na}>\mathrm{Mn}>\mathrm{Ca}>\mathrm{Zn}>\mathrm{Cu}>\mathrm{Pb}$. The distribution of the concentration of metals in soil samples that collected from Bishoftu was $\mathrm{Fe}>\mathrm{Na}>\mathrm{Mn}>\mathrm{Ca}>$ $\mathrm{Cu}>\mathrm{Zn}>\mathrm{Pb}$. The distribution of the concentration of metals in eggplant samples that collected from Ziway was $\mathrm{Fe}>\mathrm{Na}>\mathrm{Mn}>\mathrm{Ca}>\mathrm{Zn}>\mathrm{Cu}>\mathrm{Pb}$. The results showed that the higher amounts of $\mathrm{Na}, \mathrm{Ca}, \mathrm{Zn}$ and $\mathrm{Pb}$ were obtained in the soil collected from Ziway as compared to other sample sites. The higher concentration of $\mathrm{Mn}, \mathrm{Cu}$ and $\mathrm{Fe}$ were obtained in the sample collected from Bishoftu as compared to other sample sites. The concentrations of Fe were higher than other metals concentrations and the concentrations of $\mathrm{Pb}$ were lowest than other metals concentrations in each sample site. The concentrations of $\mathrm{Ni}$ and $\mathrm{Cd}$ in soil samples were below the detection limit.

Table 6. Concentration of metals $(\mathrm{mg} / \mathrm{kg})$ in soil.

\begin{tabular}{|c|c|c|c|c|c|}
\hline \multirow{2}{*}{ Metals } & \multicolumn{5}{|c|}{ Concentration of metals (mean \pm SD, mg/kg, $\mathrm{n}=3$ ) } \\
\cline { 2 - 6 } & Bishoftu & Koka & Alemtena & Meki & Ziway \\
\hline $\mathrm{Na}$ & $1,016 \pm 1$ & $1,083 \pm 1$ & $1,320 \pm 2$ & $843 \pm 1$ & $1,120 \pm 2$ \\
\hline $\mathrm{Ca}$ & $266 \pm 1$ & $248 \pm 2$ & $396 \pm 1$ & $237 \pm 1$ & $788 \pm 1$ \\
\hline $\mathrm{Mn}$ & $763 \pm 1$ & $649 \pm 2$ & $653 \pm 1$ & $617 \pm 1$ & $628 \pm 1$ \\
\hline $\mathrm{Fe}$ & $5,508 \pm 1$ & $4,714 \pm 1$ & $5,010 \pm 2$ & $4,970 \pm 1$ & $5,355 \pm 1$ \\
\hline $\mathrm{Cu}$ & $74.0 \pm 0.2$ & $50.7 \pm 0.2$ & $58.3 \pm 0.2$ & $51.3 \pm 0.2$ & $74.0 \pm 0.2$ \\
\hline $\mathrm{Zn}$ & $44.8 \pm 0.2$ & $55.5 \pm 0.2$ & $73.9 \pm 0.4$ & $51.5 \pm 0.5$ & $99.4 \pm 0.2$ \\
\hline $\mathrm{Pb}$ & $15.0 \pm 0.1$ & $14.9 \pm 0.1$ & $13.8 \pm 0.1$ & $14.8 \pm 0.2$ & $15.8 \pm 0.2$ \\
\hline $\mathrm{Ni}$ & $\mathrm{BDL}$ & $\mathrm{BDL}$ & $\mathrm{BDL}$ & $\mathrm{BDL}$ & BDL \\
\hline $\mathrm{Cd}$ & $\mathrm{BDL}$ & $\mathrm{BDL}$ & $\mathrm{BDL}$ & $\mathrm{BDL}$ & BDL \\
\hline
\end{tabular}

\section{Physicochemical properties of soil}

The physicochemical properties of soil of the eggplant farmlands are given in Table 7. The $\mathrm{pH}$ of the farmland soil lied between 6.81 and 8.13. The highest $\mathrm{pH}(8.13)$ was found in Koka farmland soil and the lowest $\mathrm{pH}$ (6.81) was found in Bishoftu farmland soil. Thus, the $\mathrm{pH}$ of all the farmland soil samples was near to neutral and in the normal $\mathrm{pH}$ range of soil $6.5-8.4$ recommended for the cultivation of vegetables. The highest EC of $303 \mu \mathrm{s}$ and TDS of $176 \mathrm{mg} / \mathrm{L}$ were found in Ziway farmland soil, and the lowest conductivity of $208 \mu \mathrm{s}$ and TDS of $124 \mathrm{mg} / \mathrm{L}$ were found in Bishoftu farmland soil. The salinity of all the farmland soil was in the range 0.1$0.3 \%$.

Table 7. Mean concentration (mean $\pm \mathrm{SD}$ ), $\mathrm{pH}$, conductivity, salinity and total dissolved solid of soil sample.

\begin{tabular}{|c|c|c|c|c|}
\hline Sample site & $\mathrm{pH}$ & $\mathrm{EC}(\mu \mathrm{s})$ & Salinity $(\%)$ & TDS $(\mathrm{mg} / \mathrm{L})$ \\
\hline Bishoftu farmland & $6.81 \pm 0.02$ & $208 \pm 4$ & 0.1 & $124 \pm 3$ \\
\hline Koka farmland & $8.13 \pm 0.03$ & $282 \pm 2$ & 0.2 & $134 \pm 2$ \\
\hline Meki farmland & $7.60 \pm 0.04$ & $293 \pm 5$ & 0.3 & $133 \pm 3$ \\
\hline Alemtena farmland & $7.80 \pm 0.03$ & $287 \pm 3$ & 0.2 & $143 \pm 2$ \\
\hline Ziway farmland & $8.10 \pm 0.02$ & $303 \pm 3$ & 0.2 & $176 \pm 3$ \\
\hline
\end{tabular}


Transfer factor of metals from soil to plants

Transmission of metals from soil to plant is studied using an index called transfer factor (TF). It is calculated as a ratio of the concentration of a metal in the plant to the concentration of metal in soil both represented in the same units. If TF is higher or equals to one, the absorption of metal from soil by the plant is higher. On the other hand, lower value of TF indicates the poor response of plants towards metal absorption and the plant can be used for human consumption. Loading and accumulation of metals in the soil depend on different factors such as the chemical form of elements, $\mathrm{pH}$, and organic matter content as well as electric conductivity [30].

Metal transfer factor from soil to plant is a key component of human exposure to metals via the food chain. Table 8 summarizes the TF of metals for eggplants collected from five farmlands. The TF of metals in eggplant was in the order $\mathrm{Na}>\mathrm{Ca}>\mathrm{Zn}>\mathrm{Pb}>\mathrm{Cu}>\mathrm{Mn}>\mathrm{Fe}$. The TF value of $\mathrm{Na}$ is higher than the other metals in all the sample sites with $\mathrm{TF}>1$. This indicates that the $\mathrm{Na}$ may get accumulated in the eggplant from other sources (water, fertilizers and air). The TF values of the other metals $(\mathrm{Ca}, \mathrm{Mn}, \mathrm{Fe}, \mathrm{Cu}, \mathrm{Zn}$ and $\mathrm{Pb}$ ) were less than one in all the sample sites. This indicates lower uptake of metals by eggplant from the soil. The lower TF values indicate the poor response of plants toward metal absorption and the plants can be used for human consumption.

Table 8. Transfer factor (TF) values of eggplant samples.

\begin{tabular}{|c|c|c|c|c|c|}
\hline Metals & \multicolumn{5}{|c|}{ Sample sites } \\
\hline & Bishoftu & Koka & Alemtena & Meki & Ziway \\
\hline $\mathrm{Na}$ & 1.43 & 1.77 & 1.41 & 1.64 & 1.43 \\
\hline $\mathrm{Ca}$ & 0.486 & 0.460 & 0.399 & 0.506 & 0.171 \\
\hline $\mathrm{Mn}$ & 0.052 & 0.053 & 0.046 & 0.071 & 0.070 \\
\hline $\mathrm{Fe}$ & 0.017 & 0.018 & 0.011 & 0.015 & 0.016 \\
\hline $\mathrm{Cu}$ & 0.086 & 0.085 & 0.111 & 0.195 & 0.091 \\
\hline $\mathrm{Zn}$ & 0.399 & 0.328 & 0.356 & 0.419 & 0.293 \\
\hline $\mathrm{Pb}$ & 0.282 & 0.302 & 0.130 & 0.196 & 0.229 \\
\hline
\end{tabular}

Analysis of variance (ANOVA)

Analysis of variance (ANOVA) uses the F statistic to compare whether the difference between sample means of two or more sets of data is significant or not. If $F_{\text {calculated }}>F_{\text {critical }}$, it means sample means are significantly different. If $\mathrm{F}_{\text {calculated }}<\mathrm{F}_{\text {critical }}$, sample means are not significantly different. During the processes of sample preparation and analysis, a number of random errors may be introduced in each aliquot and in each replicate measurement. The variation in sample mean of the analyte was tested by using ANOVA, whether the source of variation was from experimental procedure or heterogeneity among the samples (i.e. difference in mineral contents of soil, water, atmosphere; variation in application of agrochemicals like fertilizers, pesticides, herbicides etc or other variations in cultivation procedures). The ANOVA results (Table 9) showed that there were significant differences in the mean values of $\mathrm{Na}, \mathrm{Ca}, \mathrm{Mn}, \mathrm{Zn}$ and $\mathrm{Pb}$ between eggplant samples but there was no significant difference in the mean values of $\mathrm{Fe}$ and $\mathrm{Cu}$ between the samples. The ANOVA results (Table 9) showed that there were significant differences in the mean values of $\mathrm{Na}, \mathrm{Ca}, \mathrm{Mn}, \mathrm{Fe}, \mathrm{Cu}$ and $\mathrm{Zn}$ between the soil of eggplant but there was no significant difference in the mean values of $\mathrm{Pb}$ between the soil samples. 
Table 9. Analysis of variance (ANOVA) in eggplant and soil samples at 95\% confidence level.

\begin{tabular}{|c|c|c|c|c|c|c|c|}
\hline Parameters & $\mathrm{Na}$ & $\mathrm{Ca}$ & $\mathrm{Mn}$ & $\mathrm{Fe}$ & $\mathrm{Cu}$ & $\mathrm{Zn}$ & $\mathrm{Pb}$ \\
\hline \multicolumn{8}{|c|}{ Eggplant } \\
\hline $\mathrm{F}_{\text {Calculated }}$ & 55.4 & 38.5 & 32.4 & 0.445 & 2.00 & 6.60 & 29.0 \\
\hline$F_{\text {Critical }}$ & 3.48 & 3.48 & 3.48 & 3.48 & 3.48 & 3.48 & 3.48 \\
\hline $\mathrm{p}$-value & $8.7 \times 10^{-7}$ & $4.7 \times 10^{-7}$ & $1.1 \times 10^{-5}$ & 0.774 & 0.171 & 0.007 & $1.8 \times 10^{-5}$ \\
\hline \multicolumn{8}{|c|}{ Soil } \\
\hline $\mathrm{F}_{\text {Calculated }}$ & 4.74 & 12.8 & 9.40 & 13.3 & 21.4 & 9.41 & 0.548 \\
\hline $\mathrm{F}_{\text {Critical }}$ & 3.48 & 3.48 & 3.48 & 3.48 & 3.48 & 3.48 & 3.48 \\
\hline p-value & $7.6 \times 10^{-7}$ & 0.001 & 0.002 & 0.001 & $6.9 \times 10^{-5}$ & 0.002 & 0.705 \\
\hline
\end{tabular}

Pearson correlation of metals

The Pearson correlation coefficient ( $r$ ) is used to measure the strength of linear association between two variables. A correlation coefficient of +1 indicates that there is a strong (perfect positive) correlation between the two variables. A correlation coefficient of -1 indicates that there is a strong (negative) correlation relationship between the two variables. The correlation values are categorized as no correlation $(\mathrm{r}=0.00-0.19)$, low correlation $(\mathrm{r}=0.20-0.39)$, medium correlation $(\mathrm{r}=0.40-0.59)$, higher correlation $(\mathrm{r}=0.60-0.79)$ and strong correlation $(\mathrm{r}=0.8$ $1.00)$ [31].

The correlation coefficients between metals in eggplant shows strong correlation between $\mathrm{Zn} / \mathrm{Mn}$ and $\mathrm{Cu} / \mathrm{Na}$. Medium positive correlation between $\mathrm{Mn} / \mathrm{Ca}, \mathrm{Zn} / \mathrm{Ca}, \mathrm{Cu} / \mathrm{Ca}$ and $\mathrm{Ca} / \mathrm{Na}$. $\mathrm{Pb} / \mathrm{Fe}$ and $\mathrm{Cu} / \mathrm{Mn}$ have low positive correlation. $\mathrm{Zn} / \mathrm{Cu}$ has no correlation coefficient between them. All the correlation between $\mathrm{Ca} / \mathrm{Na}, \mathrm{Mn} / \mathrm{Na}, \mathrm{Fe} / \mathrm{Na}, \mathrm{Zn} / \mathrm{Na}, \mathrm{Pb} / \mathrm{Na}, \mathrm{Fe} / \mathrm{Mn}, \mathrm{Cu} / \mathrm{Fe}, \mathrm{Zn} / \mathrm{Fe}$, $\mathrm{Zn} / \mathrm{Na}, \mathrm{Pb} / \mathrm{Ca}, \mathrm{Pb} / \mathrm{Cu}, \mathrm{Fe} / \mathrm{Ca}$ and $\mathrm{Pb} / \mathrm{Zn}$ show negative correlation.

The correlation coefficients between metals in soil shows strong correlation between $\mathrm{Cu} / \mathrm{Fe}$, $\mathrm{Pb} / \mathrm{Na}$ and $\mathrm{Pb} / \mathrm{Ca}$. Medium positive correlation between $\mathrm{Zn} / \mathrm{Na}, \mathrm{Zn} / \mathrm{Ca}, \mathrm{Fe} / \mathrm{Mn}, \mathrm{Cu} / \mathrm{Mn}, \mathrm{Zn} / \mathrm{Cu}$, $\mathrm{Fe} / \mathrm{Ca}$ and $\mathrm{Pb} / \mathrm{Mn}$. The correlation coefficients between metals $\mathrm{Ca} / \mathrm{Na}, \mathrm{Mn} / \mathrm{Na}, \mathrm{Cu} / \mathrm{Na}$ and $\mathrm{Pb} / \mathrm{Zn}$ in the soil sample have low positive correlation. The correlation coefficients between metal $\mathrm{Zn} / \mathrm{Fe}$ and $\mathrm{Pb} / \mathrm{Cu}$ in the soil have no correlation coefficient between them. All the correlations between $\mathrm{Fe} / \mathrm{Na}, \mathrm{Mn} / \mathrm{Ca}, \mathrm{Cu} / \mathrm{Ca}, \mathrm{Zn} / \mathrm{Mn}$ and $\mathrm{Pb} / \mathrm{Fe}$ have negative correlation.

\section{CONCLUSION}

The present study determined the levels of metals $\mathrm{Na}, \mathrm{Ca}, \mathrm{Mn}, \mathrm{Fe}, \mathrm{Ni}, \mathrm{Cu}, \mathrm{Zn}, \mathrm{Pb}$ and $\mathrm{Cd}$ in eggplants and their corresponding soils collected from five different sample sites in Ethiopia by FAAS. The concentration of $\mathrm{Ni}$ and $\mathrm{Cd}$ were below detection limit. The levels of metals (except $\mathrm{Fe}$ and $\mathrm{Cu}$ ) in the eggplants from five different sites were significantly different at $\mathrm{p}=0.05$. Pearson correlation coefficients showed strong positive correlation between most of the metals except $\mathrm{Na}$ which showed strong negative correlation with other metals. The investigation of the metal levels revealed that for most of the metals determined, there was a direct relationship between the levels in the eggplant and the soil in which the plant was grown. The study also showed that the metals were present at different concentrations in the samples from different sites. Comparable results were found with some of the values reported in the literature. The concentrations of $\mathrm{Pb}$ slightly exceeded the permissible levels by WHO, which could be attributed to the agricultural practices employed such as the use of fertilizer and herbicides [32, 33]. The study showed that Na transfer factor from the soil to the plant was $>1$, which indicated 
that the eggplant absorbs $\mathrm{Na}$ from other sources than soil such as water and air while Fe transfer factor was lowest indicating that it was strongly retained in the soil. Other metals showed transfer factor $<1$.

\section{ACKNOWLEDGMENTS}

The authors express their gratitude to the Department of Chemistry, Addis Ababa University, Ethiopia for providing the laboratory facilities.

\section{REFERENCES}

1. Sahoré, A.D.; Abouattier, L. Gbogouri, F.G. Assessment of some mineral elements (Ca, Na, $\mathrm{K}, \mathrm{Mg}, \mathrm{Fe}, \mathrm{Mn} \mathrm{Cu}$ and $\mathrm{Zn}$ ) and their nutritional intake of two traditional leafy vegetables: Leaves of Corchorus olitotorius (Tiliaceae) and Hibiscus sabdariffa (Malvaceae). Int. J. Agric. Innov. Res. 2014, 3, 786-791.

2. Persid, R.; Verma, V.N. Photochemical studies of Solanum melangena (eggplant) fruit by flame atomic absorption spectrometry. Int. Lett. Chem. Phys. Astron. 2014, 20, 211-218.

3. Khemnani, S.; Aswani, B.; Arora, A.; Sindal, R.S. Detection of heavy metal contents in the seed oil of Solanum malongena (eggplant) of arid zones. Int. J. Basic Appl. Chem. Sci. 2012, 2, 59-65.

4. Food and Agriculture Organization, FAOSTAT (2014), Food and Agriculture Organization of the United Nations, 2014. Retrieved from the FAOSTAT on the World Wide Web: http://faostat.fao.Org/site/567/Desktop Default.aspx?pageID=567\#ancor.

5. Pan, X.-D.; Wu, P.-G.; Jiang, X.-G. Levels and potential health risk of heavy metals in marketed vegetables in Zhejiang, China. Sci. Rep. 2016, 6, 20317. DOI: 10.1038/srep20317.

6. USDA-United States Department of Agriculture, Eggplant (raw) nutrient values and weights for edible portion (NDB No: 11209), USDA National Nutrient Database for Standard Reference, Release 21, 2008. http://www.nal.usda.gov/fnic/foodcomp/search/.

7. Yamaguchi, S.; Matsumoto, K.; Koyama, M.; Tian, S.; Watanabe, M.; Takahashi, A.; Miyatake, K.; Nakmra, K. Antihypertensive effects of orally administered eggplant (Solanum melongena) rich in acetylcholine on spontaneously hypertensive rats. Food Chem. 2019, 276, 376-382.

8. Hanson, P.M.; Yang, R.-Y., Tsou, S.C.S; Ledesma, D.; Engle, L.; Lee, T.-C. Diversity in eggplant (Solanum melongena) for superoxide scavenging activity, total phenolic, and ascorbic acid. J. Food Compos. Anal. 2006, 19, $594-600$.

9. Nisha, P.; Nazar, P.A.; Jayamurthy, P. A comparative study on antioxidant activities of different varieties of Solanum melongena. Food Chem. Toxicol. 2009, 47, 2640-2644.

10. Yeh, C.-T.; Yen, G.-C. Effect of vegetables on human phenol sulfotransferases in relation to their antioxidant activity and total phenolic. Free Radical Res. 2005, 39, 893-904.

11. Kwon, Y.-I.; Apostolidis, E.; Shetty, K. In vitro studies of eggplant (Solanum melongena) phenolics as inhibitors of key enzymes relevant for type diabetes and hypertension. Bioresour. Technol. 2008, 99, 2981-2988.

12. Meyer, R.S.; Bamshad, M.; Fuller, D.Q.; Litt, A. Comparing medicinal uses of eggplant and related Solanaceae in China, India and Philippines suggests the independent development of uses, cultural diffusion, and recent species substitutions. Econ. Bot. 2014, 68, 137-152.

13. Ismail, F.; Anjum, M.R. ; Mamon, A.N.; Kazi, T. Trace metal contents of vegetables and fruits of hyderabad retail market. Pak. J. Nutr. 2011, 10, 365-372.

14. Khair, M.H. Toxicity and accumulation of copper in Nannochloropsis oculata (Eustiginato phyceaheterokonta). World Appl. Sci. J. 2009, 6, 378-384.

15. Sharma, R.K.; Agrawal, M.; Marshall, F. Heavy metal contamination of soil and vegetables in suburban areas of Varanasi, India. Ecotoxicol. Environ. Saf. 2007, 66, 258-266. 
16. Khairiah, J.; Zalifah, M.K.; Yin, Y. H.; Aminah, A. Uptake of heavy metals by fruit type vegetables grown in selected agricultural areas. Pak. J. Biol. Sci. 2004, 7, 1438-1442.

17. Addis, W.; Abebaw, A. Determination of heavy metal concentration in soils used for cultivation of Allium sativum L. (garlic) in East Gojjam Zone, Amhara Region, Ethiopia. Cogent Chem. 2017, 3:1, 1419422. DOI: 10.1080/23312009.2017.1419422.

18. Mccauley, A.; Jones, C.; Jacobsen, J. Soil and Water Management Module I, Basic Soil Properties, Montana State University Extension Service: USA; 2005.

19. Kadam, P.M. Study of pH and electrical Conductivity of Soil in Deulgaon Raja Taluka, Maharashtra. Int. J. Res. Appl. Sci. Eng. Technol. 2016, 4, 399-402.

20. Kiliçel, F. Determination of heavy metal levels in some vegetable types abundant in Van City, Turkey. Rev. Anal. Chem. 2005, 24, 311-322.

21. Demirezen, D.; Aksoy, A. Heavy metal levels in vegetables in Turkey are within safe limits for $\mathrm{Cu}, \mathrm{Zn}$, Ni and exceeded for $\mathrm{Cd}$ and Pb. J. Food Qual. 2006, 29, 252-265.

22. Rashid, M.H.; Fardous, Z.; Chowdhury, M.A.Z.; Alam, M.K.; Rahman, M.A.; Uddin, M.A.; Jahan, I. Micronutrients analysis in eggplant, spinach and water of Tangail District in Bangladesh. Adv. Biochem. Biotechnol. 2015, 1, 1-13.

23. Uddin, N.; Islam, M.A.; Baten, M.A. Heavy metal determination of brinjal cultivated in soil with wastes. Progr. Agric. 2016, 27, 453-465.

24. Weldegebriel, Y.; Chandravanshi, B.S.; Wondimu, T. Concentration levels of metals in vegetables grown in soils irrigated with river water in Addis Ababa. Ecotoxicol. Environ. Saf. 2012, 77, 57-63.

25. Kitata, R.B.; Chandravanshi, B.S. Concentration levels of major and trace metals in onion (Allium cepa L.) and irrigation water around Meki Town and Lake Ziway, Ethiopia. Bull. Chem. Soc. Ethiop. 2012, 26, 27-42.

26. Mekonnen, K.N.; Ambushe, A.A.; Chandravanshi, B.S.; Redi-Abshiro, M.; McCrindle, R.I. Assessment of potentially toxic elements in Swiss chard and sediment of Akaki River, Ethiopia. Toxicol. Environ. Chem. 2014, 96, 1501-1515.

27. Lakew, A.; Chandravanshi, B.S.; Belay, A.; Behailu, G. Effect of cooking time on selected metals, oxalate and phytate contents of the raw and cooked lettuce from five farms in Ethiopia. Chem. Int. 2018, 4, 15-23.

28. Thermo Electron Corporation. Orion 162A, Orion Benchtop Conductivity Meter, Instruction Manual, Thermo Electron Corporation: USA; 2003.

29. Codex Alimentarius Commission, Joint FAO/WHO food standards programme codex committee on contaminants in foods, Fifth Session, The Hague, The Netherlands, 2011.

30. Ogoko, E.C. Accumulation of heavy metal in soil and their transfer to leafy vegetables with phytoremediation potential. Am. J. Chem. 2015, 5, 125-131.

31. Melina, V.; Craig, W.; Levin, S. Position of the academy of nutrition and dietetics: Vegetarian diets. J. Acad. Nutr. Diet. 2016, 116, 1970-1980.

32. Davenport, J.R.; Peryea, F.J. Phosphate fertilizers influence leaching of lead and arsenic in a soil contaminated with lead arsenate. Water, Air, Soil Pollut. 1991, 57, 101-110.

33. Defarge, N.; Spiroux de Vendômois, J.; Séralini, G.E. Toxicity of formulants and heavy metals in glyphosate-based herbicides and other pesticides. Toxicol. Rep. 2018, 5, 156-163. 